history of civilisation becomes a study of scientific causes and human consequences, and not a continuous chronological record of the growth of natural knowledge.

For the education of most young citizens, therefore, whom Sir Frederick Hopkins appears to have in mind, we suggest that what is wanted is not the history of science as such but of its social and industrial influences. "No one," said Comte, "can be really master of any science unless he studies its special history, which again is bound up, at every step, with the general history of humanity." We have often been reminded in recent years of these social and economic contacts; and it is upon them that the chief emphasis should be placed when attention to the history of science is being advocated for students in schools or universities.

\section{Preservation of Wild Life in India}

$\mathrm{A}^{\mathrm{N}}$ appeal made by the Association for the Provinces of India, in the first report of the Association recently issued (Agra: Hasan Manzil, Shahganj) shows the need for concentrated and swift action in its support. For long years this area of India has suffered heavily; in part from the toll of life taken by sportsmen, and in part by the natives under one pretext or another. It is not only the existence of the larger mammals which is threatened, but also of bird-life, especially of the ducks, which have been, and are being, destroyed by thousands either by shooting or by netting.

The existing close-season regulations are more honoured, we are told, in the breach than in the observance, while the issue of licences to all and sundry is reckless; and these include not merely ordinary firearms but quick-firing and magazine rifles. A plea is urged for a revision of the present system of licensing and an embargo on shooting from motor-cars, over water-holes and salt-licks, and between the hours of sunset and sunrise. It is proposed to reduce the abuses which now exist in licences for the protection of crops. Here, as in Africa and elsewhere, this need for 'protection' has again been advanced for commercial ends.

Having regard to the innumerable devices which exist in the United Provinces for the slaughter of game, there is no occasion for surprise at the note of alarm which has been sounded. In some areas which were once prolific, game has been absolutely wiped out. All good sportsmen, we feel sure, will deplore the state of affairs which now exists, and will join hands with those who are anxious to beat out the fires of destruction before they spread further, for there is still a remnant of a glorious heritage to be saved.

More than this; the members of this Association realise that they are the trustees for posterity. The present generation has no right to slay until the slaying stops for lack of victims. It is their duty to see that this does not happen; and this not so much in order that generations yet unborn may have something left to shoot, but that those who come after us may be able to make amends for our own abuse of the opportunities presented for the right use of this game.

Hitherto, game has been simply exploited, either to serve the ends of 'sport', or of commerce. Of the haunts and habits of these creatures, all that has come to light only suffices to guide those bent on killing to their prey. The tiger knows as much. What is needed is a concentrated study of the various types of game as they live their daily lives, unsuspecting the presence of man. Here we shall find the key to the problems presented by their evolution-what governs their choice of food, and its abundance, what governs their coloration, and their 'behaviour' in varying circumstances, their adjustments to their environment, and a hundred other similar problems.

These aspects in the life-history of gameanimals never entered the heads of the older sportsmen : they are beyond the ken of the native shikaree. But they will be of vital importance to those who come after us; and we have no right to deprive them of their birthright, merely to satisfy the thirst for securing records, and 'trophies'.

The United Provinces, and the world at large, owe a debt which cannot easily be repaid, to His Excellency the Governor, Sir William Malcolm Hailey, the patron of the Association, and to its founders, the joint honorary secretaries, Major J. Corbett and Mr. Hasan Abid Jafry, who are sparing no efforts not merely to secure the necessary legislation, but also, what is quite as important, to spread a knowledge of the wild-life of India among the rising generation, by propaganda work. The Association seems at present to be the only one of its kind in India, but as conditions in the United Provinces apply also to many other parts of the country, it may be hoped that similar organisations for the preservation of game will be established. 